\title{
EDITORIAL
}

\section{Uso da Pesquisa em Ensino de Física na prática docente}

Há sinais alvissareiros neste número, bem como nos próximos, de que vem crescendo o número de pesquisadores da área de Pesquisa em Ensino de Física (PEF) no Brasil e América Latina que têm escolhido a RBEF como instrumento de divulgação dos resultados de suas pesquisas. É uma demonstração inequívoca de que a RBEF pode atuar em complementação ao aclamado periódico Investigações em Ensino de Ciências (http://www.if.ufrgs.br/public/ensino/revista.htm), editado por Marco Antonio Moreira, que tem caráter mais restrito pois se destina exclusivamente para a investigação de temas de ensino/aprendizagem de ciências propriamente ditos.

Como a RBEF pretende alcançar uma abrangência maior procurando abordar ainda aspectos culturais, instrucionais e históricos da Física relevantes ao seu ensino e atingir um público mais amplo formado por professores do ensino médio e superior, estudantes de graduação e pós-graduação, e demais interessados no ensino de Física e Ciências de uma modo geral, urge realçar aqui uma questão recorrente que permeia inúmeras discussões em foros nacionais e internacionais. De que forma professores de Física podem se beneficiar das pesquisas do processo ensino/aprendizagem de ciências? Que efeitos podem causar nas disciplinas de cursos de licenciatura em física, tais como Práticas de Ensino e Instrumentação para o Ensino nem sempre ministradas por especialistas na área devido ao ainda incipiende número deles ou por políticas internas excludentes dos departamentos de física profissionais?

Em um interessante Guest Comment do American Journal of Physics de abril de 2001, Don Holcomb, do Departamento de Física da Universidade Cornell, levanta alguns pontos que podem ser úteis àqueles docentes que desejam melhorar a eficácia de suas aulas nos cursos de graduação e pós-graduação, mas têm que enfrentar responsabilidades outras, tais como fazer pesquisa de ponta em Física, manter regularidade na produção científica - do contrário perdem a bolsa do $\mathrm{CNPq}_{-}$, orientar estudantes, participar da administração, elaborar projetos, submeter-se a uma carga didática pesada, etc. Um dos pontos-chaves é a definição de alguns critérios que permitam ao docente avaliar a utilidade e o possível impacto daquela pesquisa na melhoria da qualidade do processo de ensino/aprendizagem. "Convém ressaltar que PEF parece mais pesquisa em Ciências Sociais do que pesquisa em Física. Seu campo de estudo é gente e não matéria inanimada", assinala Holcomb. Após um relato de suas preferências com relação à pesquisa na área desenvolvida nos Estados Unidos, Holcomb apela para todos os não pesquisadores em Ensino de Física para que evitem o velho e popular preconceito contra qualquer mudança substancial no ensino: "Eu aprendi física de um certo modo e atingi um nível bastante satisfatório de conhecimento. Assim, vou ensinar do jeito que aprendi. Se os estudantes de hoje se esforçarem vão aprender do mesmo modo que eu." E qual a situação no Brasil? O que os docentes brasileiros, que não estão diretamente envolvidos, conhecem acerca da PEF? Esta é uma área de pesquisa tradicional no país. Inúmeros congressos especializados já foram realizados. Como os resultados da PEF têm sido - ou podem vir a ser - usados nas práticas docentes usuais nos cursos de Física? Para contribuir neste esforço, Susana Sousa Barros está coordenando um trabalho de levantamento e revisão bibliográfica dos principais artigos que contenham estudos básicos de fundamentação teórica, propostas concretas para a melhoria efetiva do ensino, avaliação de algumas experiências pedagógicas já realizadas no país e de material didático, paradidático e multimídia, com a finalidade de publicação na RBEF de uma Resource Letter nacional sobre a produção nacional em PEF. Sugestões são muito bem vindas.

Nelson Studart

Editor 